\title{
A Convenient Preparation of Thieno[3,2-c]pyrazole ${ }^{1}$
}

John Airey, ${ }^{2}$ Matthieu Barrague, ${ }^{3}$ Michael L. Edwards, ${ }^{2}$ Michael Ferro, ${ }^{2}$ Dirk Friedrich, ${ }^{2}$ Timothy A. Gillespy, ${ }^{3}$ John Jurcak, ${ }^{3}$ Kwon Musick, ${ }^{3}$ Philip M. Weintraub*4

sanofi-aventis, 1041 Route 202-206, P.O. Box 6800, Bridgewater, NJ 08807-0800, USA

E-mail: philipmweintraub@gmail.com

Received: 08.08.2013; Accepted after revision: 03.10.2013

Abstract: A practical synthesis of multigram quantities of $1 H$-thieno[3,2-c]pyrazole is presented in which the Jacobson reaction serves as the key step.

Key words: aminations, cyclizations, polycycles, heterocycles

Pyrazoles are an important class of biomolecules. Biologically active pyrazoles include lonazolac, ${ }^{5}$ apixaban, ${ }^{6}$ crizotinib, ${ }^{7}$ and rutolitinib. ${ }^{8}$ Condensed pyrazoles such as $1 H$-indazole (1) have become important pharmaceutical scaffolds. Less well known are thienopyrazoles, such as $1 H$-thieno[3,2-c]pyrazole (2) and $1 H$-thieno[2,3-c]pyrazole (3). It is known that thiophene is an acceptable bioisostere for benzene and, therefore, thienopyrazoles 2 and 3 should serve as substitutes for indazole (Figure 1).<smiles>c1ccc2[nH]ncc2c1</smiles>

1

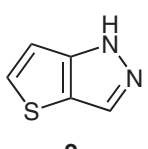

2

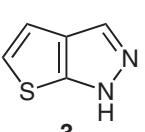

Figure 1 Condensed pyrazoles

To support studies related to the synthesis of potential kinase inhibitors, we needed large quantities of thieno[3,2c]pyrazole (2). Two syntheses of $\mathbf{2}$ have been reported by Gronowitz and co-workers ${ }^{9}$ (Scheme 1). The first synthesis started from 3-bromothiophene-2-carbaldehyde (4), which was subjected to aromatic nucleophilic substitution with sodium azide to give azide 5 in $48 \%$ yield. ${ }^{10}$ Treatment of azide 5 with hydrazine hydrate in boiling ethanol containing a small amount of acetic acid gave the desired thieno[3,2-c]pyrazole (2). In the second method, also starting from azide $\mathbf{5}$, the azide group was reduced to amine $\mathbf{6}$, which was then diazotized. Reduction of the resulting diazonium salt 7 gave thieno[3,2-c]pyrazole (2). Thus, 2 was available in a $7.7 \%$ overall yield by a two-step sequence or in a $5.7-12 \%$ yield through a four-step sequence. These syntheses are unsatisfactory for preparing the larger amounts of $\mathbf{2}$ required for preparation of analogues of the compound. Here, we describe our efforts to develop a more efficient route to $1 H$-thieno[3,2-c]pyrazole (2).

SYNTHESIS 2014, 46, 0096-0100

Advanced online publication: 28.11 .2013

DOI: 10.1055/s-0033-1338577; Art ID: SS-2013-M0539-OP

(C) Georg Thieme Verlag Stuttgart · New York

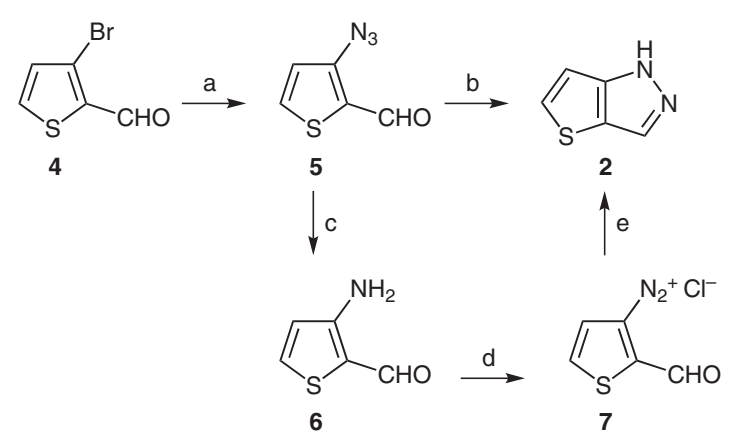

Scheme 1 Previous synthesis of $1 H$-thieno[3,2-c]pyrazole. Reagents and conditions: (a) $\mathrm{NaN}_{3}, \mathrm{DMSO}, 65{ }^{\circ} \mathrm{C}, 48 \mathrm{~h}, 48 \%$ yield; (b) $\mathrm{N}_{2} \mathrm{H}_{4} \cdot \mathrm{H}_{2} \mathrm{O}, \mathrm{AcOH}$, EtOH, $16 \%$ yield; (c) $\mathrm{H}_{2} \mathrm{~S}$, EtOH; (d) $\mathrm{NaNO}_{2}$, $\mathrm{HCl}$; (e) $\mathrm{Na}_{2} \mathrm{~S}_{2} \mathrm{O}_{4}, 12-25 \%$ yield (3 steps).

A possible route to $\mathbf{2}$, which we discarded, involved reduction of the nitro imine $\mathbf{8}$ by triethyl phosphite to give the 2-arylthieno[3,2-c]pyrazole 9 (Scheme 2). ${ }^{11}$ We felt that this route suffered from difficulties in obtaining the starting material and from the need to remove the N2 substituent. Cyclizations of azo compounds ${ }^{12}$ and of diazonium salts ${ }^{13}$ are commonly used methods for the synthesis of condensed pyrazoles such as indazole. A variant on this is the Jacobson reaction. ${ }^{14}$ This reaction converts orthomethyl amines into pyrazoles through $\mathrm{N}$-acetylation, nitrosation, and cyclization, ${ }^{15}$ and may proceed via the diazonium salt. ${ }^{14 \mathrm{c}}$ To apply this reaction to the synthesis of $1 H$-thieno[3,2-c]pyrazole, we needed sufficient quantities of 2-methylthiophene-3-amine (11). This amine, in turn, should be obtainable from commercially available methyl 3-aminothiophene-2-carboxylate (10).

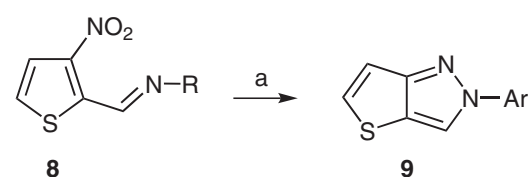

Scheme 2 Discarded route to $1 H$-thieno[3,2-c]pyrazole. Reagents and conditions: (a) $(\mathrm{EtO})_{3} \mathrm{P}, t-\mathrm{BuPh}$.

We knew that anthranilic acid (12) gives $o$-toluidine (13) on reduction with aluminum hydride ${ }^{16}$ (Scheme 3 ), so we initially used this procedure to reduce ester 10. However, the preparation of aluminum hydride was always a daunting task, so we sought a more expedient reduction and we noted that use of lithium aluminum hydride in refluxing 1,4-dioxane had been reported to reduce the ethoxycar- 
bonyl group in esters $\mathbf{1 4}$ directly to the methyl group in carbazoles 15 (Scheme 3). ${ }^{17}$<smiles>CC(=O)c1ccccc1N</smiles><smiles>[R]c1c(C(C)(C)C)cc2c([nH]c3ccccc32)c1C</smiles><smiles>CCCCCCCC(=O)OCCCC</smiles>

Scheme 3 Reagents and conditions: (a) $\mathrm{AlH}_{3}, \mathrm{Et}_{2} \mathrm{O}$; (b) $\mathrm{LAH}, 1,4-$ dioxane, reflux.

We found that when a solution of ester $\mathbf{1 0}$ was added slowly to a suspension of lithium aluminum hydride in refluxing 1,4-dioxane, subsequent workup gave crude (2methyl-3-thienyl)amine (11), which was then used directly in the cyclization step (Scheme 4). Note that when all the reactants were mixed together at room temperature and then heated, a vigorous off-gassing occurred at $80^{\circ} \mathrm{C}$, with concomitant frothing, usually out of the flask. The reduction was uneventful, however, when the addition was performed at $70{ }^{\circ} \mathrm{C}$. Subsequently, we found that the reaction can also be carried out in refluxing tetrahydrofuran. The use of this latter solvent avoids the difficulties encountered in removing 1,4-dioxane, namely the freezing of the solvent in the condenser and distillation of some product.

Cyclization of $\mathbf{1 1}$ was effected simply by acetylation of the amine group in toluene in the presence of potassium acetate, followed by treatment of the resulting mixture with isoamyl nitrite and heating for several hours. The $\mathrm{N}$ - acetate $\mathbf{1 6}$ was readily purified by column chromatography and trituration with pentane to remove a foul-smelling impurity. The acetyl group was removed by acid hydrolysis, as reported in the literature ${ }^{1}$ or, more conveniently, by saponification with potassium hydroxide. The overall yield of this three-step sequence to unsubstituted thieno[3,2-c]pyrazole (2) was $47 \%$.

During the chromatographic purification of product $\mathbf{1 6}$, a more polar material was isolated and identified as the acetylated dimer 22. The simplest way to account for the formation of this byproduct is to assume that the starting material underwent amidation to form dimer 19 during the reduction process or that dimer $\mathbf{1 9}$ was present as an impurity in the starting material. Reduction of $\mathbf{1 9}$ to diamine 20 and subsequent processing during the Jacobson reaction would account for the formation of byproduct $\mathbf{2 2}$ (Scheme 5).

In a completely different approach, we were able to prepare thieno[3,2-c]pyrazole (2) by means of a palladiumcatalyzed cyclization reaction (Scheme 6). 3-Bromothiophene-2-carbaldehyde (23) was prepared by the method of Iddon and co-workers. ${ }^{18}$ Condensation of this material with benzophenone hydrazone (27) gave azine 24. Palladium-catalyzed addition of hydrazone $\mathbf{2 7}$ to azine $\mathbf{2 4}$ gave the bishydrazone $\mathbf{2 5}$, which was hydrolyzed with concentrated hydrochloric acid to give thieno[3,2-c]pyrazole (2) via the hydrazine aldehyde 26. The overall yield of this four-step process from commercially available 3-bromothiophene was $40.4 \%$; however, the poor atom economy (74\% of the mass of $\mathbf{2 7}$ is lost in the cyclization step) and the estimated higher cost per gram of the final product persuaded us to favor the Jacobson reaction.

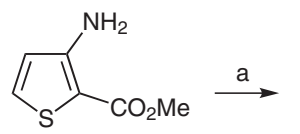

10

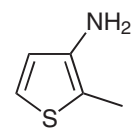

11
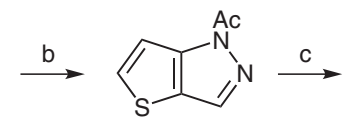

16

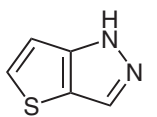

2

Scheme 4 Reagents and conditions: (a) LAH, 1,4-dioxane, 70-101 ${ }^{\circ} \mathrm{C}$; (b) $\mathrm{KOAc}, \mathrm{Ac}_{2} \mathrm{O}$, toluene, r.t. to $46{ }^{\circ} \mathrm{C}$ then $\mathrm{Me}_{2} \mathrm{CH}\left(\mathrm{CH}_{2}\right)_{2} \mathrm{ONO}, 80-$ $104{ }^{\circ} \mathrm{C}, 4-6 \mathrm{~h}, 52 \%$ yield (from 10); (c) $\mathrm{KOH}, \mathrm{EtOH}, 90 \%$ yield.

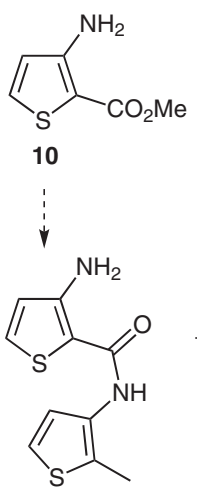

19

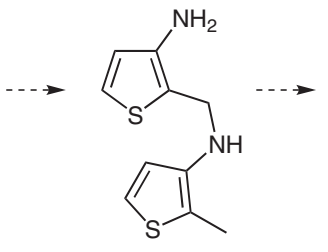

20

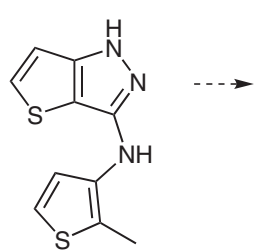

21

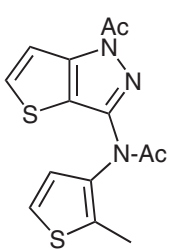

22

Scheme 5 Proposed route to the dimeric byproduct 


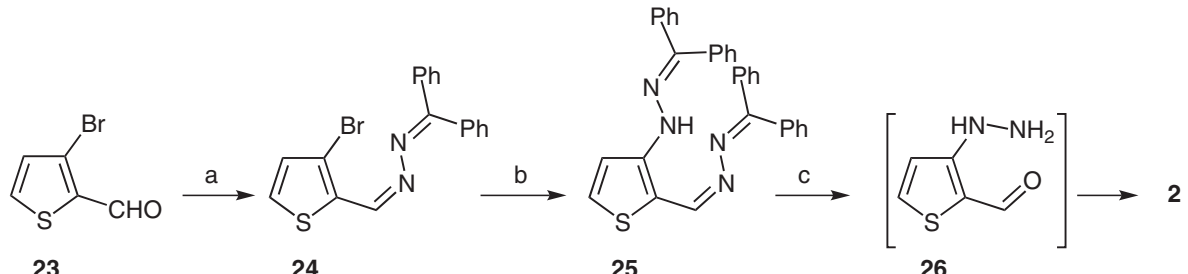

Scheme 6 Alternative synthesis of $1 H$-thieno[3,2-c]pyrazole (2). Reagents and conditions: (a) $\mathrm{Ph}_{2} \mathrm{C}=\mathrm{NNH}_{2}(\mathbf{2 7}), \mathrm{EtOH}, 70{ }^{\circ} \mathrm{C}, 30 \mathrm{~h}$; $85 \%$ yield; (b) $\mathrm{Ph}_{2} \mathrm{C}=\mathrm{NNH}_{2}$ (27), $\mathrm{Pd}(\mathrm{OAc})_{2}, \mathrm{Cs}_{2} \mathrm{CO}_{3}, 1,1^{\prime}$-bis(diphenylphosphino)ferrocene (dppf), toluene, $100{ }^{\circ} \mathrm{C}, 24 \mathrm{~h}$; (c) concd $\mathrm{HCl}, \mathrm{EtOH}$, $56 \%$ yield (2 steps)

In conclusion, by using the Jacobson reaction, we developed a practical three-step process for the preparation of large (30-50 g) quantities of $1 H$-thieno[3,2-c]pyrazole (2) in reasonable yield starting from a commercially available material. We also prepared $\mathbf{2}$ through palladium-catalyzed amination of thiophene as the key step.

Melting points were determined with a Thomas-Hoover capillary melting point apparatus and are uncorrected. TLC analyses were performed with Merck DC-F254 silica gel plates, with visualization by UV irradiation. Flash chromatography was performed with Fisher 200-245 mesh chromatographic silica gel or by using ISCO RediSep silica gel cartridges. NMR spectra were recorded in $\mathrm{CDCl}_{3}$, unless otherwise stated, on a Varian Mercury-300 spectrometer operated at $300 \mathrm{MHz}$ for ${ }^{1} \mathrm{H}$ NMR and at $75.4 \mathrm{MHz}$ for ${ }^{13} \mathrm{C}$ NMR; signals are reported in ppm relative to TMS. Mass spectral data were collected on a Micromass Platform LCZ or Micromass LCT spectrometer by using the electrospray ionization technique. The organic extracts were dried over $\mathrm{MgSO}_{4}$ or $\mathrm{Na}_{2} \mathrm{SO}_{4}$ before evaporation under vacuum in a rotary evaporator.

\section{(2-Methyl-3-thienyl)amine (11)}

LAH Reduction: A solution of methyl 3-aminothiophene-2-carboxylate $(\mathbf{1 0}, 58.31 \mathrm{~g}, 370.9 \mathrm{mmol})$ in 1,4-dioxane $(150 \mathrm{~mL})$ was added dropwise over $1 \mathrm{~h}$, with caution, to a mechanically stirred suspension of LAH (28.16 g, $742 \mathrm{mmol})$ in anhydrous 1,4-dioxane (1.5 L) heated to $80^{\circ} \mathrm{C}$. After a further $1 \mathrm{~h}$, the mixture was cooled to 5-10 ${ }^{\circ} \mathrm{C}$ in an ice-water bath and the excess reagent was decomposed by successive cautious dropwise addition of $\mathrm{H}_{2} \mathrm{O}(28 \mathrm{~mL}), 15 \%$ aq $\mathrm{NaOH}(28 \mathrm{~mL})$, and $\mathrm{H}_{2} \mathrm{O}(56 \mathrm{~mL}) . \mathrm{Et}_{2} \mathrm{O}(400 \mathrm{~mL})$ was added, and the mixture was stirred for $2 \mathrm{~h}$. The solids were removed by filtration and washed with $\mathrm{Et}_{2} \mathrm{O}(3 \times 200 \mathrm{~mL})$. The combined filtrate and wash were concentrated to afford give a brown liquid $\left[{ }^{1} \mathrm{H}\right.$ NMR: $\delta=2.22(\mathrm{~s}, 3 \mathrm{H}), 3.32(\mathrm{br} \mathrm{s}, 2 \mathrm{H}), 6.56(\mathrm{~d}, 1 \mathrm{H}), 6.89(\mathrm{~d}, 1 \mathrm{H})]$ that was used directly, without further purification, in the next step.

Alane reduction: An oven-dried three-necked flask fitted with a reflux condenser and a $\mathrm{N}_{2}$ inlet was charged with $\mathrm{AlCl}_{3}(5.33 \mathrm{~g}, 40$ mmol) and $\mathrm{Et}_{2} \mathrm{O}(50 \mathrm{~mL})$. The magnetically stirred mixture was cooled in an ice-water bath then treated cautiously with a solution of LAH (749 mg, $20 \mathrm{mmol})$ in $\mathrm{Et}_{2} \mathrm{O}(15 \mathrm{~mL})$ and stirred for $20 \mathrm{~min}$. A solution of methyl 3-aminothiophene-2-carboxylate $(\mathbf{1 0}, 1.57 \mathrm{~g}$, $10 \mathrm{mmol})$ in $\mathrm{Et}_{2} \mathrm{O}(15 \mathrm{~mL})$ was added dropwise. The mixture was allowed to warm to r.t. and then refluxed overnight. The cooled mixture was diluted with $\mathrm{Et}_{2} \mathrm{O}(59 \mathrm{~mL})$ and treated dropwise with $\mathrm{H}_{2} \mathrm{O}$. Vigorous evolution of gas occurred. The mixture was poured into $\mathrm{H}_{2} \mathrm{O}(200 \mathrm{~mL})$ and extracted with EtOAc $(5 \times 100 \mathrm{~mL})$. The organic extracts were combined and concentrated to give an orange oil $(0.92 \mathrm{~g})$ that was purified by chromatography (silica gel) before use in the next step.
1-Acetyl-1 $H$-thieno[3,2-c]pyrazole (16)

Amine 11 was dissolved in toluene $(600 \mathrm{~mL})$ and the solution was treated with KOAc $(34.37 \mathrm{~g}, 350 \mathrm{mmol})$. The vigorously stirred mixture was treated by dropwise addition of $\mathrm{Ac}_{2} \mathrm{O}(97.6 \mathrm{~mL}, 864.9$ $\mathrm{mmol}$ ) over about $20 \mathrm{~min}$. The temperature rose rapidly from 23 to $46^{\circ} \mathrm{C}$ during the first half of the addition. ${ }^{19}$ The flask containing the mixture was then placed in an oil bath heated to $80{ }^{\circ} \mathrm{C}$. When the reaction temperature reached $75^{\circ} \mathrm{C}$, isoamyl nitrite $(66.7 \mathrm{~mL}, 496.4$ $\mathrm{mmol}$ ) was added dropwise over $30 \mathrm{~min}$. The temperature rose slowly to $104^{\circ} \mathrm{C}$. After $4 \mathrm{~h}$, heating was discontinued and the reaction was stirred overnight at r.t. The solids were removed by filtration and washed with toluene $(3 \times 200 \mathrm{~mL})$. The organic phases were combined and concentrated to form a black liquid from which crystals deposited on standing. The mixture was dissolved in a small amount of $\mathrm{CH}_{2} \mathrm{Cl}_{2}$, diluted with heptane-10\% EtOAc and purified in by flash chromatography [silica gel $(7.2 \times 25 \mathrm{~cm})$, heptane- $10 \%$ EtOAc $(1.7 \mathrm{~L})$ then heptane-15\% EtOAc (4 L)]. The fractions $(500$ $\mathrm{mL}$ each) containing the pure product were combined and concentrated to afford a yellow solid [38.55 g (62\%)] that was stirred with pentane $(300 \mathrm{~mL})$ for $4 \mathrm{~h}$, then collected by filtration, washed with pentane $(2 \times 100 \mathrm{~mL})$, and dried to give a light-beige solid; ${ }^{20}$ yield: $32.53 \mathrm{~g}(52 \%)$.

${ }^{1} \mathrm{H}$ NMR $\left(300 \mathrm{MHz}, \mathrm{CDCl}_{3}\right): \delta=2.75(\mathrm{~s}, 3 \mathrm{H}), 7.58(\mathrm{~s}, 2 \mathrm{H}), 7.90$ (s, $1 \mathrm{H})$.

${ }^{13} \mathrm{C}$ NMR $\left(75.4 \mathrm{MHz}, \mathrm{CDCl}_{3}\right): \delta=21.75,113.78,128.84,134.25$, $135.28,147.36,188.81$

Anal. Calcd for $\mathrm{C}_{7} \mathrm{H}_{6} \mathrm{~N}_{2} \mathrm{OS}$ : C, 50.59; H 3.64; N, 16.85; S, 19.29 . Found: C, 50.49; H, 3.38; N, 16.84; S, 19.21 .

$\mathrm{N}$-(1-Acetyl-1H-thieno[3,2-c]pyrazol-3-yl)- $N$-(2-methyl-3-thienyl)acetamide (22)

A more polar material was also eluted from the column. Concentration of these fractions gave an orange oil $[1.1 \mathrm{~g}(2 \%)]$ that crystallized on standing to a beige solid.

${ }^{1} \mathrm{H} \mathrm{NMR}\left(300 \mathrm{MHz}, \mathrm{CDCl}_{3}\right): \delta=2.15(\mathrm{br} \mathrm{s}, 3 \mathrm{H}), 2.36(\mathrm{~s}, 3 \mathrm{H}), 2.47$ $(\mathrm{s}, 3 \mathrm{H}), 6.91(\mathrm{~d}, J=5.5 \mathrm{~Hz}, 1 \mathrm{H}), 7.20(\mathrm{~d}, J=5.5 \mathrm{~Hz}, 1 \mathrm{H}), 7.50(\mathrm{~d}$, $J=5.5 \mathrm{~Hz}, 1 \mathrm{H}), 7.56(\mathrm{~d}, J=5.5 \mathrm{~Hz}, 1 \mathrm{H})$.

${ }^{13} \mathrm{C}$ NMR $\left(75.4 \mathrm{MHz}, \mathrm{CDCl}_{3}\right): \delta=12.43,21.32,23.48,113.52$, 122.06, 126.27, 134.06, 135.88, 144.45, 147.42, 168.34, 170.78.

Anal. Calcd for $\mathrm{C}_{14} \mathrm{H}_{13} \mathrm{~N}_{3} \mathrm{O}_{2} \mathrm{~S}_{2}: \mathrm{C}, 52.64 ; \mathrm{H} 4.10 ; \mathrm{N}, 13.16 ; \mathrm{S}, 20.08$. Found: C, 52.92; H, 3.92; N, 12.82; S, 20.03 .

\section{$1 H$-Thieno[3,2-c]pyrazole (2)}

Acid Hydrolysis: 1-Acetylthieno[3,2-c]pyrazole (16; 20.9 g, 126 $\mathrm{mmol})$ was suspended in EtOH $(120 \mathrm{~mL})$ and dissolved by gentle heating. $\mathrm{H}_{2} \mathrm{O}(120 \mathrm{~mL})$ and concd aq $\mathrm{HCl}(120 \mathrm{~mL})$ were added successively, and the mixture was heated at $60{ }^{\circ} \mathrm{C}$ for $2 \mathrm{~h}$ and then cooled. $\mathrm{K}_{2} \mathrm{CO}_{3}(30 \mathrm{~g})$ was added in portions and the resulting mixture was filtered. The filtrate was concentrated and its $\mathrm{pH}$ was adjusted to 5 by addition of further $\mathrm{K}_{2} \mathrm{CO}_{3}$. The solution was then extracted with EtOAc $(5 \times 200 \mathrm{~mL})$. The extracts were combined, washed with brine $(1 \times 100 \mathrm{~mL})$, dried, filtered through Celite, and 
concentrated. The resulting solid was crystallized (EtOAc) to give tan needles; yield: $14.1 \mathrm{~g} \mathrm{(90 \% ).}$

${ }^{1} \mathrm{H}$ NMR (300 MHz, $\mathrm{CDCl}_{3}$ ): $\delta=7.02(\mathrm{~d}, 1 \mathrm{H}), 7.41(\mathrm{~d}, 1 \mathrm{H}), 7.79$, (s, $1 \mathrm{H}), 10.0-10.6$ (br s, $1 \mathrm{H})$.

${ }^{1} \mathrm{H}$ NMR $\left(75.4 \mathrm{MHz}\right.$, DMSO- $\left.d_{6}\right): \delta=7.07(\mathrm{~d}, 1 \mathrm{H}), 7.56(\mathrm{~d}, 1 \mathrm{H})$, $7.71+8.00(\mathrm{~s}+\mathrm{s}, 0.6 \mathrm{H}+0.4 \mathrm{H}), 12.98+13.30(\mathrm{br} \mathrm{s}+\mathrm{br} \mathrm{s}, 0.6 \mathrm{H}$ $+0.4 \mathrm{H}$ ). This spectrum showed that 2 exists as a mixture of the N1$\mathrm{H}$ and $\mathrm{N} 2-\mathrm{H}$ tautomers in a ratio of 3:2.

LC/MS (ESI): $m / z=125.02$.

Anal. Calcd for $\mathrm{C}_{5} \mathrm{H}_{4} \mathrm{~N}_{2} \mathrm{~S}$ : C, 48.37; $\mathrm{H} 3.25 ; \mathrm{N}, 22.56$. Found: $\mathrm{C}$, 48.17; H, 3.20; N, 22.57 .

Base Hydrolysis: A solution of 1-acetylthieno[3,2-c]pyrazole (16, 9.75 g. $58.66 \mathrm{mmol})$ in $\mathrm{MeOH}(100 \mathrm{~mL})$ was treated with $\mathrm{KOH}$ $(3.29 \mathrm{~g}, 58.63 \mathrm{mmol})$ and the mixture was heated at $60{ }^{\circ} \mathrm{C}$ for $3 \mathrm{~h}$. The cooled mixture was concentrated, and the residue was partitioned between EtOAc $(150 \mathrm{~mL})$ and $\mathrm{H}_{2} \mathrm{O}(150 \mathrm{~mL})$. The separated aqueous layer was extracted with more EtOAc $(2 \times 100 \mathrm{~mL})$. The organic layers were combined, washed with brine $(20 \mathrm{~mL})$, dried, filtered through a plug of silica gel $(10 \mathrm{~g})$, and concentrated to give a yellow solid $(7.39 \mathrm{~g})$. Crystallization (EtOAc-heptane) gave beige needles; yield: $6.58 \mathrm{~g}(90 \%)$; $\mathrm{mp} 156-158{ }^{\circ} \mathrm{C}$.

${ }^{1} \mathrm{H}$ NMR (300 MHz, DMSO- $d_{6}$ ): $\delta=7.11(\mathrm{~d}, J=5.4 \mathrm{~Hz}, 1 \mathrm{H}), 7.60$ $(\mathrm{d}, J=5.4 \mathrm{~Hz}, 1 \mathrm{H}), 7.77(\mathrm{br} \mathrm{s}, 1 \mathrm{H}), 12.99(\mathrm{br} \mathrm{s}, 1 \mathrm{H})$.

LC/MS (ESI): $m / z=125$.

MS (ESI): $m / z=125[\mathrm{M}+1]$.

\section{3-Bromo-2-thiophenecarboxaldehyde (23)}

A solution of 3-bromothiophene (30.0 g, $184 \mathrm{mmol})$ in THF (200 $\mathrm{mL}$ ) cooled to $0{ }^{\circ} \mathrm{C}$ was added slowly to a $2.0 \mathrm{M}$ solution of LDA in THF ( $92 \mathrm{~mL}, 184 \mathrm{mmol}$; Aldrich Chemicals). The orange solution was stirred at $0{ }^{\circ} \mathrm{C}$ for $30 \mathrm{~min}$, then piperidine-1-carbaldehyde $(20.4 \mathrm{~mL}, 184 \mathrm{mmol})$ was added. The mixture was stirred for a further $1 \mathrm{~h}$ then diluted with $\mathrm{Et}_{2} \mathrm{O}(300 \mathrm{~mL})$, washed with brine $(100 \mathrm{~mL})$, dried, and concentrated. The resulting orange oil was purified by chromatography (silica gel, heptane-EtOAc). Productcontaining fractions were combined and concentrated to give an orange liquid; ${ }^{21}$ yield: $29.3 \mathrm{~g}(85 \%)$.

\section{(1Z)-1-[(3-Bromo-2-thienyl)methylene]-2-(diphenylmeth-}

\section{ylene)hydrazine (24)}

A mixture of 3-bromo-2-thiophenecarboxaldehyde (23; $29.3 \mathrm{~g}, 153$ $\mathrm{mmol})$ and benzophenone hydrazone $(\mathbf{2 6} ; 33.1 \mathrm{~g}, 168 \mathrm{mmol})$ in EtOH $(200 \mathrm{~mL})$ was stirred at $70{ }^{\circ} \mathrm{C}$ for $20 \mathrm{~h}$. The mixture was cooled to r.t. and the solids were collected by filtration to give a yellow solid $(42.7 \mathrm{~g})$. The filtrate was concentrated and the resulting slurry was triturated with EtOH to give additional 24 (4 g); total yield: $46.7 \mathrm{~g}(82 \%)$.

LC/MS (ESI): $m / z=369.00[\mathrm{M}+1]$.

(2Z)-1-(Diphenylmethylene)-2-(\{3-[2-(diphenylmethylene)hydrazino]-2-thienyl $\}$ methylene)hydrazine (25)

A mixture of azine 24 (46.6 g, $126 \mathrm{mmol})$, benzophenone hydrazone (26; $29.7 \mathrm{~g}, 151 \mathrm{mmol}), \mathrm{Pd}(\mathrm{OAc})_{2}(2.12 \mathrm{~g}, 9.5 \mathrm{mmol}), \mathrm{Cs}_{2} \mathrm{CO}_{3}$ (69.8 g, $214 \mathrm{mmol})$, dppf (10.5 g, $18.9 \mathrm{mmol})$ and toluene was stirred at $100{ }^{\circ} \mathrm{C}$ for $24 \mathrm{~h}$, then cooled to r.t. The solids were removed by filtration and the solvent was evaporated to give the crude product that was used in the next reaction.

LC/MS (ESI): $m / z=485[\mathrm{M}+1]$.

\section{H-Thieno[3,2-c|pyrazole (2) from Hydrazine 25}

The crude hydrazine 25 was dissolved in EtOH $(500 \mathrm{~mL})$ and the solution was treated with concd. aq $\mathrm{HCl}(250 \mathrm{~mL})$. The mixture was heated at $80{ }^{\circ} \mathrm{C}$ for $3 \mathrm{~h}$ then cooled. $\mathrm{H}_{2} \mathrm{O}(1.5 \mathrm{~L})$ and EtOAc $(500$ $\mathrm{mL}$ ) were added, followed by $\mathrm{Na}_{2} \mathrm{CO}_{3}$ until the $\mathrm{pH}$ was neutral. The aqueous layer was separated and extracted with EtOAc $(3 \times 250 \mathrm{~mL})$. The organic layers were combined, dried, filtered, and concentrated to give a brown oil that was purified by chromatography (silica gel, heptane-10\% EtOAc to heptane- $40 \%$ EtOAc). Product-containing fractions were combined and concentrated to give a pink solid; yield: $9 \mathrm{~g}(56 \%)$.

\section{References}

(1) Heterocycles, part 14. For part 13, see: Weintraub, P. M. J. Heterocycl. Chem. 1993, 30, 1635.

(2) Current address: Retired.

(3) Current address: Chemical Research, Sanofi US, 153 2nd Ave, Waltham, MA 02451, USA.

(4) Current address: 33 Casale Drive South, Warren, NJ 07059, USA.

(5) (a) Görtz, R.; Appelboom, T. Int. J. Tissue React. 1985, 7, 263. (b) Vinge, E.; Bjorkman, S. B. Acta Pharmacol. Toxicol. 1986, 59, 165.

(6) (a) Pinto, D. J. P.; Orwat, M. J.; Koch, S.; Rossi, K. A.; Alexander, R. M.; Smallwood, A.; Wong, P. C.; Rendina, A. R.; Luettgen, J. M.; Knabb, R. M.; He, K.; Xin, B.; Wexler, R. R.; Lam, P. Y. S. J. Med. Chem. 2007, 50, 5339. (b) Martin, M. T.; Nutescu, E. A. Curr. Med. Res. Opin. 2011, 27, 2123.

(7) Cui, J. J.; Tran-Dubé, M.; Shen, H.; Nambu, M.; Kung, P.P.; Pairish, M.; Jia, L.; Meng, J.; Funk, L.; Botrous, I.; McTigue, M.; Grodsky, N.; Ryan, K.; Padrique, E.; Alton, G.; Timofeevski, S.; Yamazaki, S.; Li, Q.; Zhou, H.; Christensen, J.; Mroczkowski, B.; Bender, S.; Kania, R. S.; Edwards, M. P. J. Med. Chem. 2011, 54, 6342.

(8) Lin, Q.; Meloni, D.; Pan, Y.; Xia, M.; Rodgers, J.; Shepard, S.; Li, M.; Galya, L.; Metcalf, B.; Yue, T.-Y.; Liu, P.; Zhou, J. Org. Lett. 2009, 11, 1999.

(9) Gronowitz, S.; Westerlund, C.; Hörnfeldt, A. B. Chem. Scr. $1977,12,1$.

(10) Gronowitz, S.; Westerlund, C.; Hörnfeldt, A. B. Acta Chem. Scand., Ser. B 1975, 29, 224.

(11) Colburn, V. M.; Iddon, B.; Suschitzky, H.; Gallagher, P. T. J. Chem. Soc., Chem. Commun. 1978, 453.

(12) (a) Dell'Erba, C.; Novi, M.; Petrillo, G.; Tavani, C. Tetrahedron 1992, 48, 325. (b) Dell'Erba, C.; Novi, M.; Petrillo, G.; Tavani, C. Tetrahedron 1994, 50, 3529. (c) Fusco, R.; Marchesini, A.; Sannicolo, F. J. Heterocycl. Chem. 1987, 24, 773.

(13) (a) Bartsch, R. A.; Yang, I.-W. J. Heterocycl. Chem. 1984, 21, 1063. (b) Hoegerle, K.; L'Écuyer, P. Can. J. Chem. 1959, 37, 2068. (c) Benchidmi, M.; Bouchet, P.; Lazaro, R. J. Heterocycl. Chem. 1979, 16, 1599. (d) Wrzeciono, U.; Dudinska-Usarewicz, J.; Majewska, K.; StasieczkoRydelkiewicz, I.; Stefanowicz, J.; Nieweglowska, W. Pharmazie 1985, 40, 105. (e) Barbet, O.; Minjat, M.; Petavy, A.-F.; Paris, J. Eur. J. Med. Chem. 1986, 21, 359. (f) Kazimierczuk, Z.; Lönnberg, H.; Vilpo, J.; Pfleiderer, W. Nucleosides Nucleotides 1989, 8, 599. (g) Sun, J.-H.; Teleha, C. A.; Yan, J.-S.; Rodgers, J. D.; Nugiel, D. A. J. Org. Chem. 1997, 62, 5627. (h) Arnautu, A.; Collot, V.; Ros, J. C.; Alayrac, C.; Witulski, B.; Rault, S. Tetrahedron Lett. 2002, 43, 2695. (i) Forbes, I. T.; Douglas, S.; Gribble, A. D.; Ife, R. J.; Lightfoot, A. P.; Garner, A. E.; Riley, G. J.; Jeffrey, P.; Stevens, A. J.; Stean, T. O.; Thomas, D. R. Bioorg. Med. Chem. Lett. 2002, 12, 3341.

(14) (a) Jacobson, P.; Huber, L. Ber. Dtsch. Chem. Ges. 1908, 41, 660. (b) Huisgen, R.; Nakaten, H. Justus Liebigs Ann. Chem. 1954, 586, 84. (c) Ruchardt, C.; Hassmann, V. Liebigs Ann. Chem. 1980, 908.

(15) (a) Ockenen, D. W.; Schofield, K. J. Chem. Soc. 1953, 1915. (b) Huisgen, R.; Bast, K. Org. Synth. Coll. Vol. V; Wiley: London, 1973, 650. (c) Ruchardt, C.; Hassmann, V. 
Synthesis 1972, 375. (d) Forster, H. E.; Hurst, J. J. Chem. Soc., Perkin Trans. 1 1973, 2901. (e) Chapman, D.; Hurst, J. J. Chem. Soc., Perkin Trans. 1 1980, 2398. (f) Pellegrin, V.; Fruchier, A.; Elguero, J. J. Labelled Compd. 1981, 18, 999. (g) Bailey, R. J.; Card, P. J.; Shecter, H. J. Am. Chem. Soc. 1983, 105, 6096. (h) Gueiffier, A.; Milhavet, J. C.; Blache, Y.; Chavignon, O.; Teulade, J. C.; Madesclaire, M.; Viols, H.; Dauphin, G.; Chapat, J. P. Chem. Pharm. Bull. 1990, 38, 2352. (i) Yoshida, T.; Matsuura, N.; Yamamoto, K.; Doi, M.; Morie, T.; Shimada, T.; Kato, S. Heterocycles 1996, 43, 2701. (j) Mewshaw, R. E.; Nelson, J. A.; Shah, U. S.; Shi, X.; Mazandarani, H.; Coupert, J.; Marquis, K.; Brennen, J. A.; Andree, T. H. Bioorg. Med. Chem. Lett. 1999, 9, 2593. (k) Miller, R. B.; Stowell, J. G.; Dugar, S.; Moock, T. E.; Jenks, C. W.; Farmer, S. C.; Phan, B.; Wujcik, C. E.;

Olmstead, M. M. Tetrahedron 2002, 58, 6061. (1) Cui, J. J.; Araldi, G.-L.; Reiner, J. E.; Reddy, K. M.; Kemp, S. J.; Ho, J. Z.; Siev, D. V.; Mamedova, L.; Gibson, T. S.; Gaudette, J. A.; Minami, N. K.; Anderson, S. M.; Bradbury, A. E.; Nolan, T. G.; Semple, J. E. Bioorg. Med. Chem. Lett. 2002, 12, 2925. (m) Kourafalos, V. N.; Marakos, P.; Pouli, N.; Terzis, A.; Townsend, L. B. Heterocycles 2002, 57, 2335.

(n) Marakos, P.; Pouli, N.; Wise, D. S.; Townsend, L. B. Synlett 1997, 561. (o) Wrobleski, S. T.; Chen, P.; Hynes, J. Jr; Lin, S.; Norris, D. J.; Pandit, C. R.; Spergel, S.; Wu, H.;
Tokarski, J. S.; Chen, X.; Gillooly, K. M.; Kiener, P. A.; McIntyre, K. W.; Patil-koota, V.; Shuster, D. J.; Turk, L. A.; Yang, G.; Leftheris, K. J. Med. Chem. 2003, 46, 2110.

(16) (a) Nystrom, R. F. J. Am. Chem. Soc. 1959, 81, 610. For similar alane reductions, see also: (b) Wigfield, D. C.; Taymaz, K. Tetrahedron Lett. 1973, 4841. (c) Tucker, H. J. Med. Chem. 1980, 23, 1122.

(17) Moody, C. J.; Shah, P. J. Chem. Soc., Perkin Trans. 1 1989, 2463.

(18) Fuller, L. S.; Iddon, B.; Smith, K. A. J. Chem. Soc., Perkin Trans. 1 1997, 3465.

(19) An aliquot was removed and worked up by filtration, concentration of the filtrate, and chromatography of the residue. Combination and concentration of amidecontaining fractions gave $N$-(2-methyl-3-thienyl)acetamide as a light-beige solid. ${ }^{1} \mathrm{H}$ NMR: $\delta=2.18(\mathrm{~s}, 3 \mathrm{H}), 2.31(\mathrm{~s}, 3$ H), $7.01(\mathrm{~d}, 1 \mathrm{H}), 7.27(\mathrm{~d}, 1 \mathrm{H}) .{ }^{13} \mathrm{C}$ NMR: $\delta=12.25,23.73$, $120.69,124.34,126.10,131.49,167.84$. Anal. Calcd for $\mathrm{C}_{7} \mathrm{H}_{9}$ NOS: $\mathrm{C}, 54.17$; H, 5.84; N, 8.78; S, 20.66. Found: C, $53.92 ; \mathrm{H}, 5.86 ; \mathrm{N}, 8.78 ; \mathrm{S}, 20.51$.

(20) Although the Jacobson reaction has been shown to yield a mixture of $N^{1}$-acetyl and $N^{2}$-acetyl tautomers, we never obtained any of the $N^{2}$-acetyl material.

(21) Gronowitz, S.; Moses, P.; Hörnfeld, A.-B.; Hakansson, R. Ark. Kemi 1961, 17, 165. 